\title{
A hybrid solar-gas air conditioning system based on adsorption and chilled water storage
}

\author{
Antonio P. F. Leite ${ }^{1, *}$, Douglas B. Riffel ${ }^{2}$, Celina M.C. Ribeiro ${ }^{1}$, Francisco A. Belo ${ }^{1}$, Paulo \\ V.S.R. Domingos ${ }^{1}$, Daniel Sarmento ${ }^{1}$, Manoel B. Soares ${ }^{1}$, Leonaldo J. L. Nascimento ${ }^{1}$ \\ ${ }^{1}$ Solar Energy Laboratory, Federal University of Paraiba, Joao Pessoa-PB, Brazil \\ ${ }^{2}$ Mechanical Engineering Department, Federal University of Sergipe, Aracaju-SE, Brazil \\ * Corresponding author. Tel: +55 83321671 27, Fax: +55 83321677 24, E-mail: antpralon@yahoo.com.br
}

\begin{abstract}
This paper presents constructive aspects and preliminary experimental results of an adsorptive chiller as part of a $20 \mathrm{~kW}$ central air conditioning unit for providing thermal comfort in a set of rooms that comprises an area of $110 \mathrm{~m}^{2}$. Some simulation results of the air conditioner regeneration system are also presented. The cooling system is basically made up of a cold-water storage tank - supplied by an activated carbon-methanol chiller, and a hot-water storage tank - fed by a field of high efficient solar collectors with complementary heat by natural gas. The adsorber - a compact heat exchanger containing the activated carbon - was conceived and constructed in four modules, in order to allow heat and mass recovery. Other components are the same existing on conventional central air conditioners, as a condenser, an evaporator and a cooling tower. Constructive details of the collector's field, the adsorbers and the regenerating storage component are shown. The solar system is a $120 \mathrm{~m}^{2}$ collection area field composed by 76 units of a flat plate collector covered with a h igh efficient transparent insulation. Results obtained from a multi-objective optimization based on a statistic modeling shown that - for a specific cooling power of $120 \mathrm{~W} / \mathrm{kg}$ of adsorbent - the chiller's COP can reach 0.6 . With this COP value, and considering the mean value of the total daily irradiation in João Pessoa $\left(7^{\circ} 8\right.$ 'S, 34 $\left.50^{\circ} \mathrm{WG}\right)$, we can expected a solar energy cover fraction of $70 \%$, for a typical summer day. This scenario is expected for the following operation temperatures: $30^{\circ} \mathrm{C}$ for the condenser, $7^{\circ} \mathrm{C}$ for the evaporator and $105^{\circ} \mathrm{C}$ at the start of the regeneration process. For an acclimatization period of 8 hours $(9$ to $17 \mathrm{~h})$, the main dimensioning parameters were: $504 \mathrm{~kg}$ of activated carbon, 180 liters of methanol, 7,000 liters of hot water, 10,300 liters of chilled water with its temperature varying in the fan-coil from $1^{\circ} \mathrm{C}$ to $14^{\circ} \mathrm{C}$.
\end{abstract}

Keywords: Solar-gas adsorptive chiller, Thermal storage, Numerical simulation.

\section{Introduction}

The simplicity of operation and minimal requires of maintenance of the adsorption chiller are certainly the major advantages compared to conventional liquid chiller (vapor compression) and to absorption chiller.

The scope of this technology involves besides the sectors of commerce and service, also the industrial, and it becomes possible the large-scale use of 'trigeneration' (combined heat, power and cooling).

The system consists basically of 3 components: an activated carbon-methanol adsorption chiller (water-cooling unit), a chilled water storage tank and an air-water heat exchanger (fancoil). The schematic diagram of the system operation is shown in Fig.1.

The adsorption chiller is made up of the following main devices: four adsorbers (heat exchangers porous media/liquid), disposed in a parallel-series arrangement, one hot water storage tank supplied by solar energy and natural gas, two air condensers, one evaporator, and accessories such as valves and circulation pumps. 


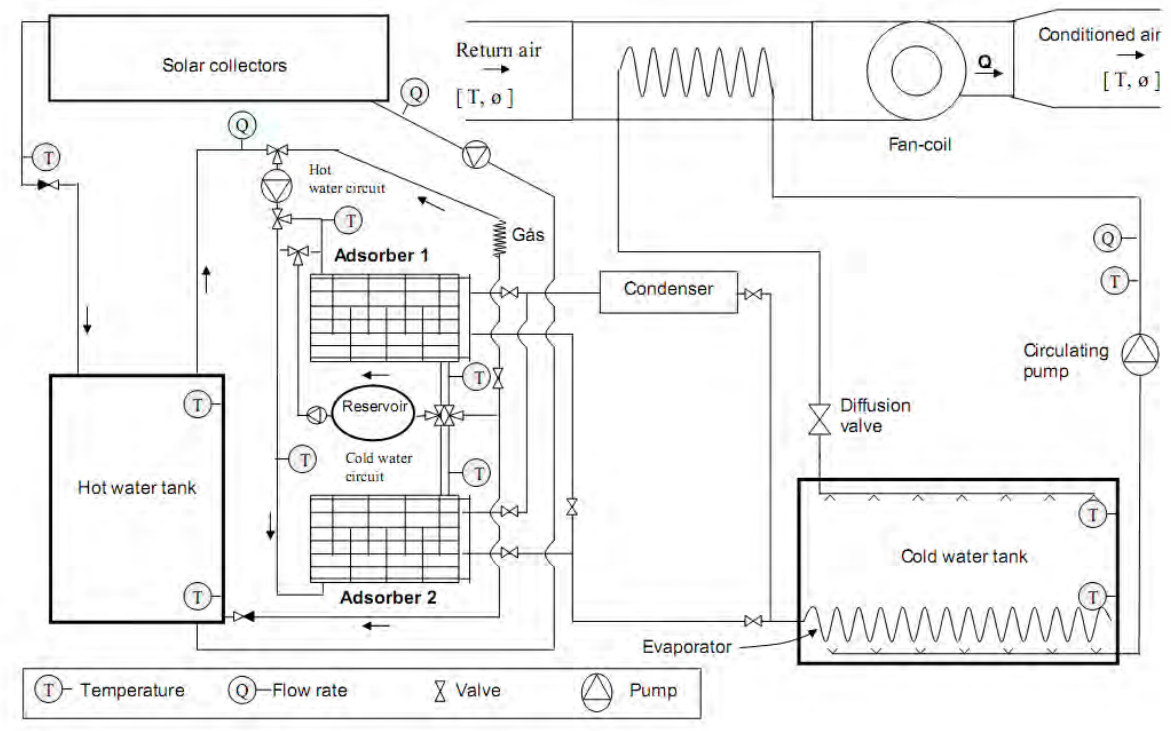

Fig.1. Scheme operation of the adsorption chiller fed by solar energy and natural gas, with thermal storage of chilled water (1).

\section{Methodology}

For dimensioning the adsorptive air conditioning system, we used a detailed study of individual components by means of a computer simulation program, using initially the analysis of each component and then the entire integrated system.

The computational simulation, called ADSOL, was carried out using the calculation program in the Simulink interface, with functions created in Matlab ${ }^{\circledR}$ to simulate the operation of the solar collectors field connected to the hot water storage tank and the adsorption chiller (2). For the collectors and the chiller, empirical correlations and simple methods of energy balance were used. For the storage tank, the function was based on the finite volume method.

The simulation of the complete system aims to determine the seasonal variations of different operating parameters such as the temperature, the efficiency of solar collectors, the coefficient of performance (COP) and the specific cooling power (SCP). With these data it is possible to adjust the operating times and other parameters of the system operation.

\subsection{Solar collectors}

For modeling the field of solar collectors it was used the quadratic efficiency collector Eq.(1) (3), which estimates the average efficiency of a solar collector at a given time, from the temperature difference between the collector $(T)$ and the environment $\left(\mathrm{T}_{e n v}\right)$ and from the solar radiation (Rad) at that moment. The constants $a_{0}, a_{1}$ and $a_{2}$ depend on the characteristics of the collector, as the overall coefficient of thermal loss to the environment and the relationship between the transparent and the total area. It also takes into account the arrangement of the collectors (parellel-series) that was disposed in two sets of 38 collectors each one.

$\eta=a_{0}-a_{1} \frac{T-T_{e n v}}{\operatorname{Rad}}-a_{2} \frac{\left(T-T_{e n v}\right)^{2}}{\operatorname{Rad}}$

The Eq.(2) represents a simple energy balance for each collector: 
$T_{i}=T_{i-1}+\frac{\eta A \cdot \operatorname{Rad}}{\dot{V}_{c o l} C_{p} \rho}$

Where, $\mathrm{Ti}$ is the temperature of the $\mathrm{i}$-th collector in serie, $A$ is the transparent area, $\dot{V}_{\text {col }}$ is the water flow in each collector in parallel, $c_{p}$ is the specific heat of the water and $\rho$ is the density of the water (properties taken in the inlet temperature).

\subsection{Adsorption chiller}

The adsorption chiller operation was simulated using a model developed by Riffel et al. (4). It was investigated statistically the results of the dynamic model of the adsorber in order to obtain the optimum project parameters, taking into account the best operating points and the influence of seven variables (temperature and mass flow of hot water, cycle length, number of tubes, number of fins, fin thickness and material of manufacture) (5). The results showed that all variables are statistically significant and interdependent. In other words, a change in one variable affects directly the other one. This demonstrates the importance of using statistical modeling for this analysis. As a main result, we observed that the COP is highly dependent on the number of fins, the material and the cycle length. The inner surface of the adsorber, exchange heat with water from a hot or cold source, depending on the phase of the cycle. The adsorbent occupies the space delimited by the external wall of the tube and the corrugated fins. The adsorbent bed operates under vacuum for getting the required thermodynamic properties of the working fluid (the methanol). The micropores of the adsorbent medium has a diameter smaller than $2 \mathrm{~nm}$. In the case of specific cooling power (SCP), the most important variables were the number of fins, the number of tubes and the hot water temperature.

The Eq.(3) represents an energy balance for the water that flows in the adsorber. Losses in the pipeline and the delayed response in thermal heat exchanger (adsorber) were not considered.

$T_{\text {out }}=T_{\text {in }}-\frac{S C P}{C O P} \cdot \frac{m_{a d s}}{\dot{V}_{a d} c_{p} \rho}$

Where, $T_{\text {out }}$ and $T_{\text {in }}$ are, respectively, the water temperatures at the exit and entry of the adsorbers, $m_{a d s}$ is the total mass of adsorbent (activated carbon), and ${ }_{\dot{V}_{a d}}$ is the water flow in the adsorber.

\subsection{Hot water tank}

The geometry of the hot water storage tank is cylindrical, with is connected at the bottom and the top, with the solar collectors and the adsorbers. For calculating the heat exchanges in the tank the finite volume method was used and it was considered a stratified tank with onedimensional heat transfer. The stratification occurs in layers of increasing density and decreasing temperature. This method presents a numerical solution that enables problem solving under any initial conditions and it consists in dividing the tank into a finite number of longitudinal nodes of same temperature and volume. Thus, we obtained the equations of the heat and mass transfers for each volume, applying the respective boundary conditions. The solution of the equations is performed by implicit formulation and the method of matrix inversion. The model of the hot water tank was developed by Riffel (2), by changing only the response of simulation to provide temperature values in both the base and on top of the tank. 


\section{Description of the central air conditioning unit}

The air conditioning system is based on an adsorption cycle with heat recovery, in which the steps of regeneration and production of refrigeration effect occur simultaneously, i.e., the adsorbers (I and II, in Fig. 1) work in alternated way; when one is the adsorbing phase, the other is in the desorbing phase (1). The adsorber model takes into account the geometry of the finned-tube liquid-adsorbent heat exchanger. It is based on the activated carbon-methanol pair and is responsible for cooling the water that is accumulated in the tank. The working fluid is the methanol, which flows through a compact heat exchanger evaporator, where the water is cooled. The conditioned air is obtained by changing heat with the stored chilled water and the air process through a fan-coil, and then it is distributed in the set rooms by a pipelines network. The regeneration is made by solar thermal energy produced by a highly efficient solar collectors field that is stored in a water tank, and, from this main tank to the adsorptive chiller, an additional heat is supplied by the combustion of natural gas.

\section{Constructive aspects of the central air conditioning unit}

\subsection{Regeneration system}

The regeneration system comprises a field of flat solar collectors with high efficiency, coupled to a thermal storage tank. The water previously heated by the solar energy will get the process temperature of $105^{\circ} \mathrm{C}$ with the help of a small gas heater.

\subsubsection{Solar collectors}

The solar collectors are flat and static. The outer surface of the collectors is painted nonselective matte black, and a Teflon film is placed between the absorbing surface and the glass cover plate (Fig. 2) $(6,7)$.

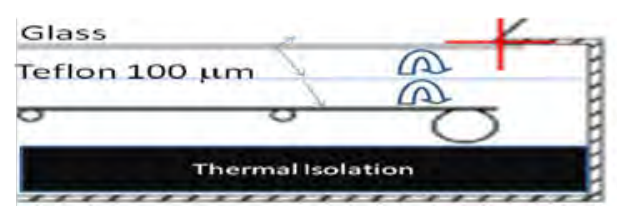

Fig. 2. Scheme of TIM cover.

The field of collectors was installed in a parallel-series arrangement, in two symmetrical blocks, each consisting of 38 units of a commercial flat collectors of $1.58 \mathrm{~m}^{2}$ each, covering a total collection area of $120 \mathrm{~m}^{2}$, installed on the roof titled $9^{\circ}$ facing to the South (Fig. 3), which corresponds to the average value for the six hottest months in João Pessoa $\left(7^{\circ} 8^{\prime} \mathrm{S}\right.$, $\left.34^{\circ} 50^{\prime} \mathrm{WG}\right)$, whose climate is typically hot and humid (8).

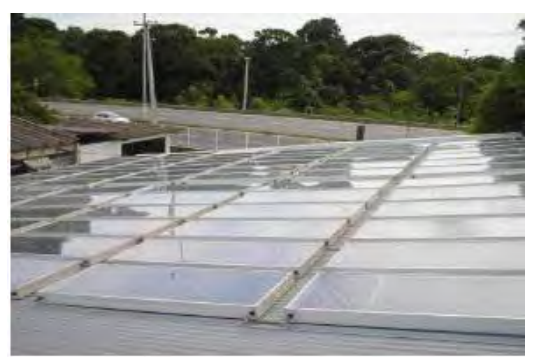

Fig. 3. Field of flat plate collectors with TIM coverage installed on the LES/UFPB. 


\subsubsection{Hot-water storage tank}

As showed in a previous article (9), the required cylindrical hot water tank for providing the minimum gas consumption was obtained from simulations to be around $7 \mathrm{~m}^{3}$ of capacity, by comparing the volumes from $1 \mathrm{~m}^{3}$ to $9 \mathrm{~m}^{3}$ during 24 hours. It was built in steel, with $2.074 \mathrm{~m}$ of diameter and $2.50 \mathrm{~m}$ of height, insulated with $50 \mathrm{~mm}$ thick polyurethane foam.

\subsubsection{Adsorptive chiller}

As result from simulations carried outd by Riffel $(4,5)$, we have determined the characteristics of the adsorber, as shown in Table 1.

Table 1. Characteristics of the adsorber.

\begin{tabular}{lc}
\hline \hline Dimensions & $668 \mathrm{~mm} \times 330.2 \mathrm{~mm} \times 19 \mathrm{~mm}$ \\
Number of flat tubes & 27 \\
Row number of fins & 28 \\
Tube external diameter & $12.7 \mathrm{~mm}$ \\
Tube internal diameter & $10.9 \mathrm{~mm}$ \\
Fin width & $19 \mathrm{~mm}$ \\
Fin thinckness & $0.3 \mathrm{~mm}$ \\
Fin pitch & $1.8 \mathrm{~mm}$ \\
Heat transfer area (fin side) & $4.175 \mathrm{~m}^{2}$ \\
\hline \hline
\end{tabular}

\subsubsection{Condenser and evaporator}

The equations related to the condenser and evaporator where widely described and experimentally validated on a previous paper (10). They are a finned-tube heat exchanger. From the simulation data, the evaporator must operate continuously (i.e., during the 24 hours a day) to ensure the storage of chilled water required by the heat exchanger air-water (fancoil) and thus provide the design temperature for the inlet air of the rooms. For the evaporator we selected a compact plate heat exchanger, manufactured by CIAT (French), for a wide power range (2 to $200 \mathrm{~kW}$ ) (11). The equipment will be adapted for the required operating conditions, to ensure that the outlet methanol is completely superheated.

\subsubsection{Natural gas heater}

The natural gas heater model GWH 300DE-GN - BOSH, will heat the water from the hot water tank until the temperature of $105^{\circ} \mathrm{C}$ to ensure the regeneration. The simulation program calculates the total amount of natural gas need to be consumed in one day.

\section{Results}

For the simulation we have taken some considerations concerning some system parameters. The chilled water temperature is considered constant and equal to $7^{\circ} \mathrm{C}$ and the cold water temperature is taken $5^{\circ} \mathrm{C}$ above ambient temperature. The mass of the adsorbent (activated carbon) is considered equal to $116 \mathrm{~kg}$ for each adsorber, and the adsorber water flow is equal to $0.1 \mathrm{~L} / \mathrm{s}$. The simulation results were obtained considering a typical summer day in Joao Pessoa, represented by the data of January 1, 2010 (10).

The water flow in each set of collectors in parallel arrangement was examined for different volumetric flows $(0.1 \mathrm{~L} / \mathrm{s}, 0.2 \mathrm{~L} / \mathrm{s}, 0.3 \mathrm{~L} / \mathrm{s}, 0.4 \mathrm{~L} / \mathrm{s}$ and $0.5 \mathrm{~L} / \mathrm{s})$ to verify which of them provides the lower gas consumption while the system reach a regeneration temperature. They are presented in different response curves generated for periods of 24 hours. 
The volumetric rate flow through the solar collectors field was measured to compare this value with those obtained in the simulation. The measure was made with an ultrasonic flow meter, mark FMS, model UFM170. The volumetric flow rate is considered constant and the average of six measured values was about $0.71 \mathrm{~L} / \mathrm{s}$.

\subsection{Figures}

The Fig. 5 shows the daily consumption of natural gas, for the water collector flow between $0.1 \mathrm{~L} / \mathrm{s}$ and $0.5 \mathrm{~L} / \mathrm{s}$.

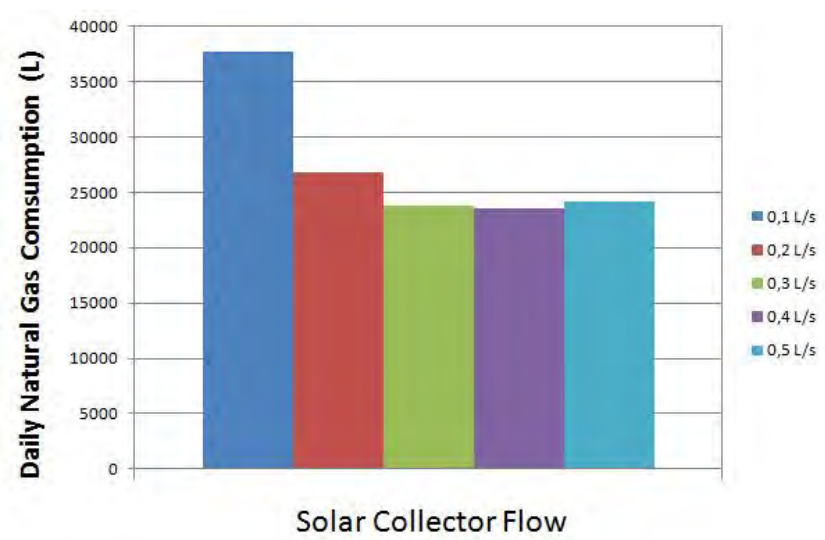

Fig. 5. Daily consumption of natural gas.

Taking into account the simulation results of Fig. 5, we can see that the solar collectors water flow of $0.4 \mathrm{~L} / \mathrm{s}$ gives the minimum consumption of natural gas. Thus, other results based on this flow rate are shown in Figs. 6 and 7.

The Fig. 6 shows the average water temperature in the hot water tank, during a whole day. The curves show that, at around $7 \mathrm{am}$ it was obtained the minimum temperature, of $58^{\circ} \mathrm{C}$, corresponding to the maximum gas flow of $0.037 \mathrm{~L} / \mathrm{s}$. The need of gas decreases with the temperature rise. Due to the thermal inertia, until the maximum temperature at $16: 10 \mathrm{~h}$ $\left(86.2^{\circ} \mathrm{C}\right)$ the gas flow increases, and then it decreases following the same tendency of the temperature.

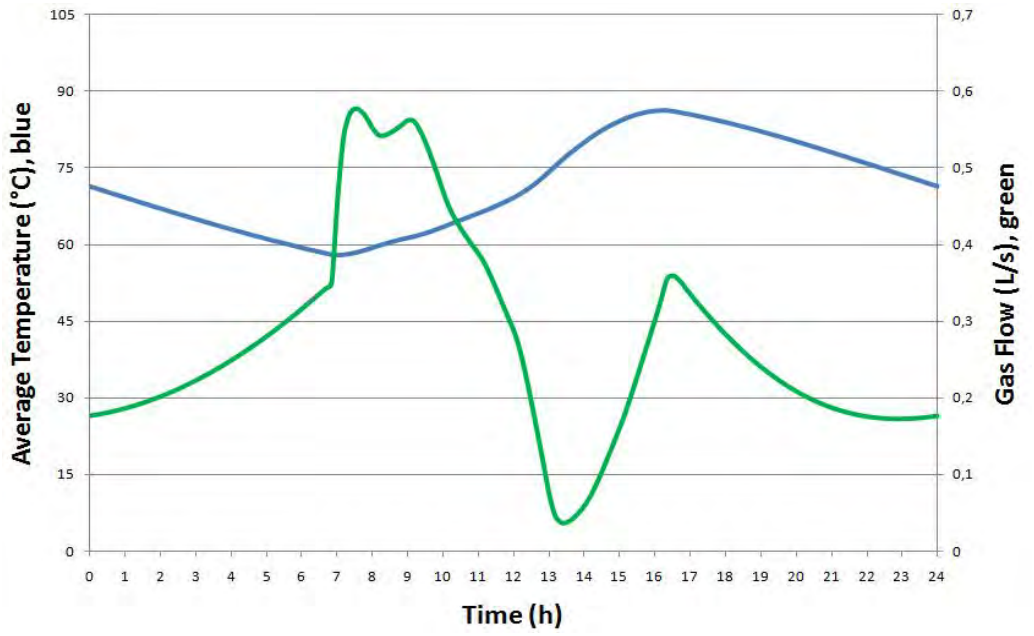

Fig.6 Average hot water temperature and the corresponding natural gas flow for the solar collector flow rate of $0.4 \mathrm{~L} / \mathrm{s}$, during a day.

The Fig. 7 shows the solar collector temperatures (blue) and the temperatures of the bottom and the top (red and green) of the storage water tank, obtained with a water flow rate of $0.4 \mathrm{~L} / \mathrm{s}$. We can see that there is an agreement between the temperature curves in the collectors 
and on the top and the bottom of the storage tank. Due to the thermal inertia, the temperature at the bottom of the tank remains almost constant until around 8am, when it begins to increase, reaching its maximum at 16:20 and then starts to decrease.

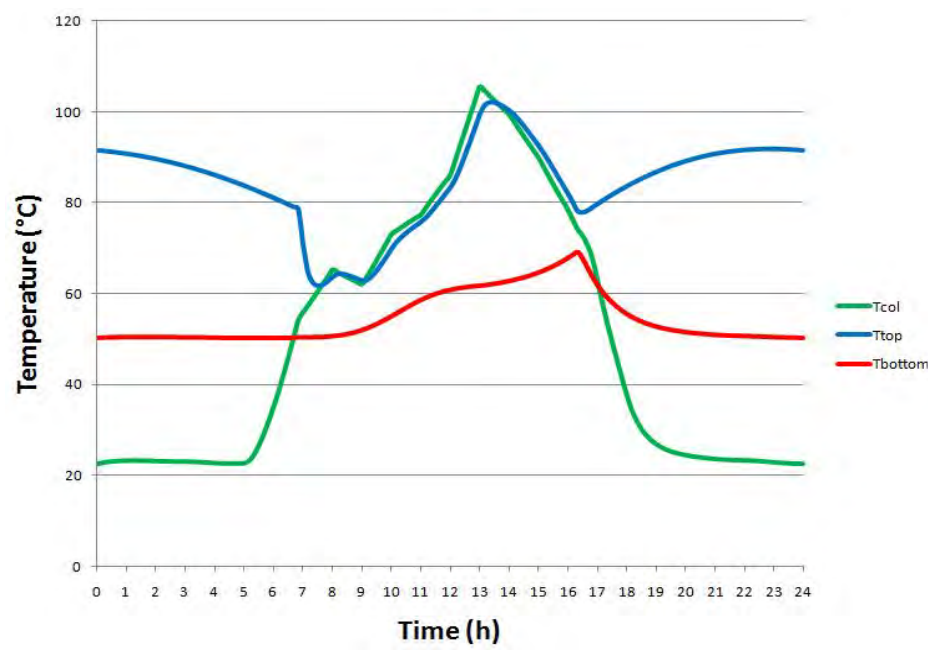

Fig.7. Thermal response of the system to the real situation, for a water flow rate of $0.4 \mathrm{~L} / \mathrm{s}$, during a day.

\section{Conclusion}

We have presented the main parameters of a central air conditioning unit based on the adsorption of methanol in activated carbon and a hybrid regeneration system, projected to provide until $70 \%$ of the required heat by solar energy, the complementary heat by natural gas. A simulation program was developed and we have obtained from it an optimal volume of the storage hot water of 7,000 liters. It was found that $0.4 \mathrm{~L} / \mathrm{s}$ is the flow rate through the solar collectors field that gives the minimum consumption of gas, and the water pump should be regulated to obtain the ideal volumetric flow.

\subsection{The current stage of the project}

The solar collectors are installed and connected to the hot water storage tank; to compensate the thermal inertia of it a small tank of 500 liters was built and connected to the main one for providing the process regeneration temperature $(105 \mathrm{oC})$ with aid of the gas heater and. An equipment for analyzing the heat losses from the storage tank was also built.

The 4 adsorber modules were made, and a test bench is now under construction. The chilled water storage tanks were manufactured and their hydraulic connections installed. The airwater heat exchanger unit (fan-coil) and their pipelines network are already installed in a set of rooms.

\section{Acknowledgements}

The authors would like to thank CNPq (CT-Petro/CNPq 15/2007) and FAPITEC/SE (FUNTEC 02/2009) for the grant support, CNPq for the post-PhD scholarship to the third author and, CAPES for PhD scholarship to the first author and for post-PhD scholarship to the second author. 


\section{References}

[1] A.P.F. Leite, F.A. Belo, M.M. Martins, D.B. Riffel, Central air conditioning based on adsorption and solar energy, Applied Thermal Engineering, Volume 31, Issue 1, January 2011, Pages 50-58, ISSN 1359-4311.

[2] D.B. Riffel, A.P.F. Leite, F.A. Belo, Simulação do a porte térmico de coletores solares planos em um tanque cilíndrico estratificado. In: I Congresso Brasileiro de Energia Solar, Fortaleza, CE, 2007.

[3] J.A. Duffie and W.A. Beckman, Solar Engineering of Thermal Processes, J. Wiley \& Sons, 1980.

[4] D.B. Riffel, Estudo Teórico e Experimental da Dinâmica e da Otimização de Refrigeradores Térmicos por Adsorção, Tese de Doutorado (Eng. Mecânica), PPGEM/UFPB, 2008.

[5] D.B. Riffel, U. Wittstadt, F.P. Schmidt, T. Nunez, F.A. Belo, A.P.F. Leite, F. Ziegler, Transient modeling of an adsorber using finned-tube heat exchanger, International Journal of Heat and Mass Transfer, Volume 53, Issues 7-8, March 2010, Pages 14731482, ISSN 0017-9310.

[6] A.P.F. Leite, F.A. Belo, M.B. Grilo, R.R.D. Andrade, Avaliação experimental de um adsorvedor multitubular coberto com material isolante transparente, Anais do V I Congresso Iberoamericano de Engenharia Mecânica (CIBEM6), Coimbra, Portugal, 1518 Oct., 2003, Vol. I, pp. 253-258.

[7] A.P.F. Leite, F.A. Belo, M.B. Grilo, R.R.D. Andrade, F. Meunier, An improved multitubular solar collector applied to adsorption refrigeration, Proc. ISES Solar World Congress, Orlando, Florida, USA, 6-12 Aug., 2005.

[8] P.V.S. Domingos, D.B. Riffel, A.C.R. Veloso, C.M.C. Ribeiro, F.A. Belo, A.P.F. Leite, Simulação numérica do sistema de regeneração de um ar condicionado solar por adsorção baseado em um campo de coletores planos de alta eficiência, IV Conferência Latino Americana de Energia Solar (IV ISES_CLA) y XVII Simposio Peruano de Enegía Solar (XVII-SPES), Cuzco, Peru, 1-5.11.2010.

[9] R.R.D. de Andrade, M.M. Machado, A. Lourenço, F.A. Belo, A.P.F. Leite, Avaliação experimental de uma cobertura isolante composta por material transparente para uso em coletor solar, V Congresso Nacional de Engenharia Mecânica - COBEM 2008, 25 a 28 de agosto, Salvador/Bahia, Brasil.

[10]D.B. Riffel, F.A. Belo, A.P.F. Leite, Otimização de chiller adsortivo solar por modelagem estatística, Climatização \& Refrigeração, Abril de 2010, pags. 38 a 45.

[11] D.B. Riffel, F.A. Belo, A.P.F. Leite, Heat and mass recovery in an activated carbonmethanol adsorptive chiller, Proceedings of COBEM 2009 - 20th International Congress of Mechanical Engineering, November 15-20, 2009, Gramado, RS, Brazil. 